\title{
Risk Factors in the Development of Rectus Sheath Hematoma and Treatment Modalities
}

\author{
Kubilay Dalci, Ahmet Gokhan Saritas, Ugur Topal*, Erdi Aydin \\ Department of General Surgery, Cukurova University, Faculty of Medicine, 01330 Cukurova/Adana, Turkey
}

${ }^{*}$ Corresponding author: Ugur Topal M.D.

Department of General Surgery

Cukurova University

Faculty of Medicine, 01100

Sarıçam/Adana Turkey

E-mail: sutopal2005@hotmail.com

\section{Rezumat}

Factorii de risc în dezvoltarea hematomului tecii rectale și a modalitătilor de tratament

Context: În acest studiu, ne propunem să prezentăm caracteristicile clinice ale pacienților cu hematom în teacă rectală $(\mathrm{RSH})$, precum şi managementul terapeutic al stării şi rezultatele.

Metode: Studiul a inclus pacienți care au fost diagnosticați şi care au primit tratament pentru RSH spontană între anii 2010 şi 2020. Caracteristicile demografice şi clinice ale pacienților, precum şi parametrii de urmărire, au fost analizate retrospectiv.

Rezultate: Studiul nostru a inclus 53 de pacienți. Numărul pacienților de sex feminin a fost de două ori mai mare decât numărul pacienților bărbați. Vârsta medie a fost de $65,7 \pm 14,68$ ani, iar $63,3 \%$ dintre pacienți aveau vârsta de peste 65 de ani. Cel mai frecvent anticoagulant utilizat a fost warfarina $(30,1 \%)$, fiind cel mai des utilizat pentru bolile de inimă $(54,7 \%)$. Valoarea raportului normalizat la momentul internării a fost de 1,93+1,18, iar valoarea hemoglobinei a fost de 11,2 gr/dl. Diametrul mediu al hematomului a fost de $74 \mathrm{~mm}$, iar cea mai frecventă etapă a fost tipul I (75,6\%). Dintre pacienți, 90,6\% au fost urmăriți conservator. Durata medie a spitalizării a fost de 15,1 zile, iar mortalitatea a apărut la opt pacienți în timpul spitalizării lor.

Concluzie: RSH spontan trebuie luat în considerare pentru femeile vârstnice care au utilizat anticoagulante. Majoritatea pacienților sunt urmăriți medical, dar mortalitatea este încă mare.

Cuvinte cheie: hematom de teacă de rect, durere abdominală, abordare conservatoare, terapie anticoagulantă, terapie chirurgicală, diagnostic 


\section{Abstract}

Background: In this study,we aim to present the clinical features of patients with rectus sheath hematoma(RSH), as well as the condition's therapeutic management and results.

Methods: The study included patients who were diagnosed with and received treatment for spontaneous RSH between the years 2010 and 2020. The demographic and clinical features of the patients, as well as follow-up parameters, were analyzed retrospectively.

Results: Our study included 53 patients. The number of female patients was twice as many as the number of male patients. The median age was $65.7 \pm 14.68$ years, and $63.3 \%$ of the patients were over the age of 65 . The most frequently used anticoagulant was warfarin (30.1\%), and it was most often used for heart diseases (54.7\%). The international normalized ratio value at the time of admission to the hospital was $1.93+1.18$, and the hemoglobin value was $11.2 \mathrm{gr} / \mathrm{dl}$. The average hematoma diameter was $74 \mathrm{~mm}$, and the most common stage was typeI (75.6\%). Of the patients, $90.6 \%$ were followed up conservatively. The average duration of hospital stay was 15.1 days, and mortality occurred in eight patients during their hospital stay.

Conclusion: Spontaneous RSH should be consideredfor elderly female patients who have used anticoagulants. Most patients are followed up medically, but mortality is still high.

Key words: rectus sheath hematoma, abdominal pain, conservative approach, anticoagulant therapy, surgical therapy, diagnosis

\section{Introduction}

Rectus sheath hematoma (RSH) is a rare cause of stomach ache, which is underestimated and has significant morbidity and mortality (1). RSH is the accumulation of blood in the anterior rectus sheath due to rupture of the epigastric veins or the rectus muscle (1). It is recognized as a "diagnostic dilemma" as it can be easily confused with the etiology of many acute abdominal pains (2). RSH is characterized by the presence of a palpable abdominal mass combined with acute abdominal pain following abdominal muscle caused by trauma, coughing, sneezing, and so on (3).

Many RSH cases are referred to as spontaneous because there is no history of trauma. Oral anticoagulation therapy or anticoagulant therapy administered with low molecular weight heparin are recognized as the most common risk factors for spontaneous RSH. Pregnancy, hypertension, previous abdominal surgery, coagulopathies, and antiplatelet therapy have also been defined as risk factors (1,4-6). Incidence of spontaneous RSH (SRSH) increases upon increased administration of antiplatelet and anticoagulant therapies, and the estimated annual rate of SRSH is between $1.2 \%$ and $1.5 \%$ (7).

Early diagnosis and treatment are necessary in SRSH to minimize complications such as hemodynamic instability, abdominal compartment syndrome, multiple organ dysfunction syndrome, and death. Treatment options include conservative, interventional, and surgical methods. Surgery can be fatal for many patients with RSH if they have other morbidities and hemorrhagic diathesis in advanced age. Therefore, the surgeon must determine the method best suited tothat specific patient. Hematoma can restrain itself with the help of conservative treatments such as bed rest, analgesia, and correction of the bleeding disorder, in many cases. Mortality can reach $4 \%$ even if SRSH restrains itself with the help of conservative treatmentand can reach $25 \%$ in patients using anticoagulants. Radical interventions are required when conservative treatment modalities fall short (7).

In the literature, data relating to $\mathrm{RSH}$ are 
based on single-center experiences and series with a limited number of patients (3,7-10).

In this study, we aim to analyze and discuss, considering the literature, the clinical features of patients diagnosed with RSH in our clinic over a period of ten years, as well as the therapeutic management of SRSH and its results.

\section{Materials and Methods}

Patients who were diagnosed with and received treatment for SRHS between 2010 and 2020 were included in the study. Patients with trauma induced hematoma, under 18 years of age, and whose data could not be gleaned were excluded from the study. A database was created based on patient files, nurses' patient observation charts, and electronic records. Patients were analyzed retrospectively with the help of the database that was created.

The demographic features; body mass indexes; comorbidities; American Society of Anesthesiologists (ASA) scores; past surgical histories; histories of anticoagulant and antiplatelet drug use and indications; laboratory parameters at the time of admission to the hospital; physical examination and radiological findings of the patients; stage, location and diameter of the RSH; treatment modalities; number of transfusions; follow-up parameters; durations of hospital stays; and mortality data were evaluated.

RSH was evaluated based on the staging system (Table l) that was created by Berná et al (11).

The clinical conditions of the patients were considered in the selection of treatment modalities. Conservative treatments included bed rest, analgesia, discontinuation of the anticoagulant, and transfusions carried out based on daily clinical follow-ups and daily follow-up of laboratory test results, while surgical therapy included hematoma drainage accompanied by ligation of the epigastric vein. Hematomas were monitored with physical examination findings and radiological imaging.

This study was carried out at a university hospital, and all data were collected and evaluated following the approval by the ethical committee thereof.

\section{Statistical Analysis}

Categorical measurements were summarized as numbers and percentages, and continuous measurements were summarized as mean and standard deviation (minimum to maximum when necessary).

\section{Results}

Our study included 53 patients. The median age was $65.7 \pm 14.68$ years, and $63.3 \%$ of the patients were over the age of 65 . The number of female patients was twice as many as the number of male patients. Cases most frequently had an ASA score of 3 (64.3\%). The most common comorbid diseases were hypertension $(50.9 \%)$ and atherosclerotic heart disease (49\%). The most frequently used anticoagulant was warfarin (30.1\%), which was most often used for heart diseases (54.7\%). The clinical and demographic features of the patients are outlined in Table 2.

The average international normalized ratio (INR) during admission to the hospital was $1.93+1.18$, and the hemoglobin value was 11.2 gr/dl. Laboratory parameters are outlined in Table 3.

The average hematoma diameter was 74 $\mathrm{mm}$, and the most common stage was type I

Table 1. Staging of spontaneous rectus hematomas based on the findings of Computerized Tomography imaging (11)

\begin{tabular}{ll}
\hline Stage 1 & Small hematomas that are confined within the rectus and do not cross the midline or dissect fascial planes \\
\hline Stage 2 & Hematoms confined within the rectus muscle but can dissect along the transversalis fascial plane or cross the midline \\
\hline Stage 3 & Large hematomas below the arcuate line that often present with blood and/or hemoperitoneum within the retzius space \\
\hline
\end{tabular}


Table 2. Clinical and demographic data of the patients

\begin{tabular}{|c|c|}
\hline Variable & $(n=53)$ \\
\hline Mean age (years) & $\begin{array}{l}65.7+14.68 \\
(26-93)\end{array}$ \\
\hline \multicolumn{2}{|l|}{ Age (years) } \\
\hline$<65$ & $20(37.7)$ \\
\hline$>65$ & $33(63.3)$ \\
\hline Sex Male & $18(33.9)$ \\
\hline Female & $35(66.1)$ \\
\hline Body Mass Index & $\begin{array}{l}28.4+5.41 \\
(17.5-43.2)\end{array}$ \\
\hline \multicolumn{2}{|l|}{ ASA Score } \\
\hline 1 & $8(15)$ \\
\hline 2 & $11(20.7)$ \\
\hline 3 & $34(64.3)$ \\
\hline \multicolumn{2}{|l|}{ Comorbidity } \\
\hline Hypertension & $27(50.9)$ \\
\hline Artheriosclerotic Heard Disase (ASHD) & $26(49)$ \\
\hline Heart failure & $20(37.7)$ \\
\hline Diabetes mellitus & $17(32.1)$ \\
\hline Arrythemia & $11(20.7)$ \\
\hline Chronic Obstructive Pulmonary Disease (COPD) & $10(18.7)$ \\
\hline Chronic Kidney Failure (CKF) & $6(11.3)$ \\
\hline Cerebrovascular Accident (CVA) & $6(11.3)$ \\
\hline Cirhosis & $5(9.4)$ \\
\hline Pulmonary Embolism & $1(1.9)$ \\
\hline Malignancy history & $11(20.7)$ \\
\hline Previous abdominal surgery & $19(35.8)$ \\
\hline \multicolumn{2}{|l|}{ Anticoagulant treatment } \\
\hline Warfarin & $16(30.1)$ \\
\hline Enoxaparin & $4(7.5)$ \\
\hline Apixaban & $1(1.9)$ \\
\hline Dabigatran & $1(1.9)$ \\
\hline \multicolumn{2}{|l|}{ Antiplatelet treatment } \\
\hline Acetylsalicylic acid & $8(15.1)$ \\
\hline Clopidogrel & $1(1.9)$ \\
\hline Acetylsalicylic acid + Clopidogrel & $4(7.5)$ \\
\hline Anticoagulant + antiplatelet treatment & $4(7.5)$ \\
\hline \multicolumn{2}{|l|}{ Indications for anticoagulant or } \\
\hline \multicolumn{2}{|l|}{ antiplatelet treatments } \\
\hline Cardiovascular diseases & $29(54.7)$ \\
\hline Cerebrovascular diseases & $3(5.7)$ \\
\hline Hematolojic diseases & $2(3.8)$ \\
\hline Malignancies & $1(1.9)$ \\
\hline
\end{tabular}

(75.6\%). The distribution of the localization of the hematoma was equal in the right and left sides of the abdomen, and the hematoma displayed bilateral localization in $22.6 \%$ of the patients. The diameter, staging, and localization details of the hematoma are outlined in Table 4.

Of the patients, $90.6 \%$ were followed up conservatively. The average duration of hospital stay was 15.1 days, and mortality occurred in eight patients during their
Table 3. Laboratory values

\begin{tabular}{ll}
\hline Variable & \\
\hline International normalized ratio & $1.93+1.18$ \\
& $(0.83-5.8)$ \\
\hline Prothrombin time (seconds) & $21.7+12.7$ \\
& $(10.4-65)$ \\
\hline Activated partial thromboplastin time (seconds) & $30.5+7.94$ \\
& $(19.3-55.5)$ \\
\hline White Blood Cell (WBC) count (mm $\left.{ }^{3} / \mathrm{L}\right)$ & $10.9+7.79$ \\
& $(4.5-58.1)$ \\
\hline Initial Hematocrit level & $34.5+6.20$ \\
& $(20.3-40.4)$ \\
\hline Hemoglobin (gr/dl) & $11.27+2.12$ \\
& $(6.1-16.5)$ \\
\hline Platelet counts (mm $3 / \mathrm{L})$ & $266.6+117.5$ \\
& $(87-632)$ \\
\hline Urea (mmol/L) & $25.0+22.84$ \\
& $(5-141)$ \\
\hline Creatinine (mmol/L) & $0.98+0.69$ \\
& $(0.44-4.1)$ \\
\hline Values are presented as mean \pm standard deviation (minimum-maximum) \\
or numbers and percentages (\%)
\end{tabular}

hospital stay. The mortalities were caused by cardiovascular and pulmonary system issues. The follow-up and treatment results are outlined in Table 5.

\section{Discussion}

$\mathrm{RSH}$ was discussed in modern literature by Richardson for the first time in 1857 (12). Although it has been a well-defined disease since its very first report, it is often misdiagnosed. Moreover, although it accounts for less than $2 \%$ of all admissions to hospital for acute abdominal pain alone, it is a pathology that should not be overlooked due to its mortality and complications $(8,13)$.

Table 4. Characteristics of the hematoma

\begin{tabular}{ll}
\hline Variable & $(\mathbf{n = 5 3 )}$ \\
\hline Diamater $(\mathrm{mm})$ & $\begin{array}{l}74+36.6 \\
(12-170)\end{array}$ \\
\hline Type & $38(75.6)$ \\
1 & $12(19.5)$ \\
2 & $3(4,9)$ \\
3 & \\
\hline Localization & $21(39.7)$ \\
Right & $20(37.7)$ \\
Left & $12(22.6)$ \\
\hline Bilateral &
\end{tabular}

Values are presented as mean \pm standard deviation (minimum-maximum) or numbers and percentages (\%) 
Table 5. Follow-up and Treatment

\begin{tabular}{ll}
\hline Variable & $(\mathbf{n}=\mathbf{5 3})$ \\
\hline Treatment & $48(90.6)$ \\
$\quad$ Medical & $4(7.5)$ \\
$\quad$ Surgical & $1(1,9)$ \\
\hline \multicolumn{1}{c}{ Percutaneous } & $4,2+3,5(1-13)$ \\
\hline Erythrocyte suspension replacement (n:22) & $6,09+11,1(1-48)$ \\
\hline Fresh Frozen plasma replacement (n:24) & $1,66+1,15(1-3)$ \\
\hline Platelet suspension replacement (n:4) & $15,1+17,2(1-79)$ \\
\hline Length of hospital stay (day) & $8(15)$ \\
\hline Mortality during hospital stay & \\
\hline Values are presented as mean \pm standard deviation (minimum-maximum) \\
or number and percentages
\end{tabular}

RSH is more common among women in their $60 \mathrm{~s}(6,10)$. This is attributed to women of increased age having a smaller amount of rectus abdomin is muscle and reduction in the flexibility of epigastric veins due to at heromatous changes in the epigastric vein walls. Another reason for increased incidence of SRSH in old age is increased use of anticoagulant and antiaggregant drugs (10). In line with the literature, most of the patients in our series were female and in their $60 \mathrm{~s}$.

Possible risk factors for RSH are trauma, rapid and sudden changes in position, anticoagulant therapy, some hematologic diseases that disrupt blood clotting mechanisms, von Willebrand disease, hypertension, obesity, recent anterior abdominal wall surgery, cough attacks due to asthma and COPD exacerbations, injections, and pregnancy $(6,7,9)$. Anticoagulant therapy has been identified as the most commonly reported risk factor for $\mathrm{RSH}$ $(1,2,6,9,10)$. Patients with cardiovascular diseases and an ASA score of 3 made up the great majority of our series. Furthermore, the average body mass index of our patients was 28.3. Two-thirds of our patients were on anticoagulant and/or antiplatelet therapy, and the average INR value was 1.93 .

RSH is diagnosed by means of imaging techniques such as ultrasonography (USG), computed tomography (CT), and magnetic resonance. The sensitivity of USG, which is the fastest and easiest diagnostic tool for patients with suspected RSH, ranges from $80 \%$ to $90 \%(14,15)$. As it is difficult to distinguish between intraabdominal lesions and abdominal lesions by means of USG, abdominal CT has become the gold standard imaging technique in the diagnosis of $\mathrm{RSH}$ (10). Furthermore, Berná et al (11) developed a classification system for RSH that considers CT results. In our study, CT imaging was the standard method used. The average hematoma diameter was identified as $74 \mathrm{~mm}$. Contrary to the series in the literature, the most common RSH in our series was type I $(75 \%)(1,7,10)$.

In the literature, surgical intervention is not recommended for RSH other than type III. Treatments such as bed rest, cessation of anticoagulants, hydration, transfusion based on decrease in hemoglobin, and fresh frozen plasma for warfarin intoxication are recommended (7). Moreover, the literature documents that success rates ranging from $80 \%$ to $90 \%$ were reported for conservative treatment $(7,16)$. Surgical treatment is recommended in patients with type III RSH whose hemodynamic stability cannot be ensured via aggressive hydration and blood transfusion. Selective embolization of the epigastric arteries must be preferred over surgery even in this patient group as open surgical interventions intensify bleeding by eliminating the buffer capacity of the hematoma. Open surgery is recommended when bleeding cannot be controlled through embolization, when the hematoma is infected, and or when compartment syndrome has developed $(1,7)$. There are a limited number of studies in the literature relating to the comparison of treatment modalities used to treat RSH. In their study comparing surgical treatment, percutaneous treatment, embolization therapy, and conservative treatment, Gradauskas et al. demonstrated that embolization of the epigastric artery is a useful method to stop bleeding in hemodynamically unstable patients. In the same study, similar results were obtained in terms of all parameters, including hematoma size, between percutaneous drainage and conservative treatment groups in patients who had type I and type II hematomas. The duration of hospital stay for patients who underwent percutaneous drainage was two times longer than for those that 
underwent conservative treatment. No serious complications associated with hematoma developed in either group, and readmission to hospital was not required. Therefore, Gradauskas et al. recommended that percutaneous drainage should be avoided as far as possible as it carries a higher risk of infection (17). Smithson et al. suggested that most cases in their series responded to conservative treatment and that selective embolization of the epigastric artery could be the first treatment option in patients using low molecular weight heparin (1). The conservative approach was primarily adopted for all patients in our series, and success was achieved in $90 \%$ of cases. One patient underwent percutaneous drainage, and four patients underwent surgical treatment. The hemodynamic balance of the patients was definitive in determining the indication for surgical treatment.

The mortality rate of RSH ranged from $12 \%$ to $20 \%$ in the studies conducted in the literature $(18,19)$. However, the rate has decreased to between $4 \%$ to $5 \%$ in recent studies. The principal reason for such a decrease in mortality rate is the inclusion of selective embolization of epigastric arteries in treatment modalities (1). In the literature, the mortality rate seems to be more related to significant comorbidities, anticoagulant therapies, large SRSHs, increased blood transfusion, and upper gastrointestinal system bleeding $(10,20)$. In our series, the incidence of mortality during hospital stay was $15 \%$, and this was not considered to be associated with RSH alone. Mortality occurred in many patients due to the aggravation of the comorbidities accompanying SRSH. Accompanying hemodynamic instability and/or comorbidities can account for increased mortality rate.

The significant limitations of our study are its retrospective design and the heterogeneity of the study population. Despite these limitations, our study provides the literature with detailed clinical data relating to this rare clinical condition.

\section{Conclusion}

SRSH is a cause of acute abdominal pain thatis more prevalent today due to an increase in the use of anticoagulant and/or antiaggregant drugs for various reasons. SRSH must be considered for patients who have a comorbidity and who use anticoagulant drugs in particular.

\section{Conflicts of Interest and Source of Funding}

No conflicts of interest were declared. We have no supportive funding.

\section{Ethical Statement}

The study was approved by the local institutional review board (05/06/2020-100/26).

\section{Orcid Numbers}

Kubilay Dalc1--- 0000-0002-3156-4269

Ahmet Gokhan Saritas---0000-0002-2039-3994

Ugur Topal --- 0000-0003-1305-2056

Erdi Aydim---0000-0003-2162-8991

\section{References}

1. Smithson A, Ruiz J, Perello R, Valverde M, Ramos J, Garzo L. Diagnostic and management of spontaneous rectus sheath hematoma. Eur $\mathrm{J}$ Intern Med. 2013;24(6) 579-582.

2. Villa M, Grande M, Rulli F, Konda D, Perretta T, Amabile D et al. Rectus sheath haematoma: are there prognostic risk factors of haemodynamic instability motivating an early operative treatment? Eur J Trauma Emerg Surg. 2012; 38(5):537-541

3. Aktürk OM, Kayllıglu SI, Aydogan I, Dinç T, Yildiz B, Cete M et al Spontaneous rectus sheath hematoma: an overview of 4-year single center experience. Indian J Surg 2015; 77(3): 1219-1221.

4. Madridano 0, Martin del Pozo M, Masso P, Gomez Cerezo JF. Hematoma del músculo recto de abdomen en pacientes tratados con heparina de bajo pesomolecular: cuatro casos clínicos. Rev Clin Esp 2011;211(2):109-110. doi: 10.1016/j.rce.2010.09.007

5. Girolami A, Allemand E, Tezza F, Pellati D, Scandellari R. Rectus muscle sheath haematoma in a patient with congenital FX deficiency and in another one with congenital FVII deficiency. Hemophilia 2010;16(1):182-185.

6. Sheth HS, Kumar R, DiNella J, Janov C, Kaldas H, Smith RE. Evaluation of risk factors for rectus sheath hematoma.Clin Appl Thromb Hemost. 2016; 22(3):292-296

7. Isik A, Peker K, Soyturk M, Firat D, Yoruker U, Yilmaz I. Diagnostic evaluation and treatment of patients with rectus abdominis hematoma. Cir Esp. 2015:93(9):580-558

8. Hatjipetrou A, Anyfantakis D, Kastanakis M. Rectus sheath hematoma: a review of the literature. Int J Surg. 2015:13:267-271.

9. Çolakoglu MK, Özdemir A, Kalcan S, Demir A, Demiral G, Pergel A. 
Spontaneous abdomen and abdominal wall hematomas due to anticoagulant/antiplatelet use: Surgeons' perspective in a single center. Ulus Travma Acil Cerrahi Derg. 2020;26(1):50-54.

10. Gündes E, Cetin DA, Aday U, Ciyiltepe $H$, Deger KC, Uzun 0 et al. Spontaneous rectus sheath hematoma in cardiac in patients: a single-center experience. Ulus Travma Acil Cerrahi Derg. 2017;23(6):483-488.

11. Berná JD, Garcia-Medina V, Guirao J, Garcia-Medina J. Rectus sheath hematoma: diagnostic classification by CT. Abdom Imaging 1996; 21(1):62-4.

12. Richardson SB. Rupture of the right rectus abdominis muscle from muscular efforts: operation and recovery, with remarks, Am. J. Med. Sci.1857;33(65):41.

13. Klingler PJ, Wetscher G, Glaser K, Tschmelitsch J, Schmid T, Hinder RA. The use of ultrasound to differentiate rectus sheath hematoma from other acute abdominal disorders, Surg Endosc .1999;13(11):1129-1134.

14. Moreno Gallego A, Aguayo JL, Flores B, Soria T, Hernández Q, Ortiz S, et al Ultrasonography and computed tomography reduce unnecessary surgery in abdominal rectus sheath haematoma. Br J Surg 1997;84(9):1295-1297.
15. Fukuda T, Sakamoto I, Kohzaki S, Uetani M, Mori M, Fujimoto T et al. Rectus sheath hematomas: clinical and radiological features. Abdom Imaging 1996;21(1):58-61.

16. Anyfantakis D, Kastanakis M, Petrakis G, Bobolakis E. Rectus sheath hematoma in a single secondary care institution: a retrospective study. Hernia. 2015; 19(3): 509-512. doi: 10.1007/s10029-013-1186-4

17. Gradauskas A, Venclauskas L, Pažusis M, Karpavicius A, Maleckas A. Comparison of the Dierent Treatment Strategies for Patients with Rectus Sheath Haematoma. Medicina. 2018;54(3):497-503.

18. Nuñez Fernandez MJ, Garcia Blanco A, García Garcia JC, Castro Paredes B, Lopez Soto A, Bon AB. Hematoma del recto anterior del abdomen: experiencia en un hospital comarcal. Rev Clin Esp 2011;211(2):85-89.

19. Carkman S, Ozben V, Zengin K, Somuncu E, Karatas A. Spontaneous rectus sheath hematoma: an analysis of 15 cases. Ulus Travma Acil Cerrahi Derg 2010;16(6):532-536.

20. Karapolat B, Tasdelen HA, Korkmaz HAA Conservative treatment of spontaneous rectus sheath hematomas: single center experience and literature review. Emerg Med Int. 2019;2019:2406873. eCollection 2019. 